\title{
In vitro antioxidant and angiotensin-converting enzyme inhibitory activity of fermented milk with different culture combinations
}

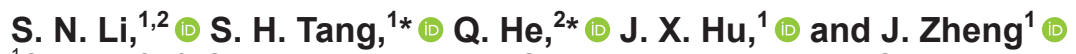 \\ ${ }^{1}$ College of Life Science and Technology, Southwest Minzu University, Chengdu 610041, P. R. China \\ ${ }^{2}$ College of Biomass Science and Engineering, Sichuan University, Chengdu 610065, P. R. China
}

\begin{abstract}
This study investigated the effects of Lactobacillus plantarum (Lp) and Bifidobacterium animalis ssp. lactis (Ba) in co-cultures with Streptococcus thermophilus (St) on changes in the acidification profile, proteolytic activity, peptide production, in vitro antioxidant activity, and angiotensin-converting enzyme (ACE) inhibitory properties of fermented milks during $21 \mathrm{~d}$ of storage at $4^{\circ} \mathrm{C}$. The $\mathrm{pH}$ values and proteolysis in all batches showed a gradual decrease and increase during storage, respectively. The ACE-inhibitory activity and total antioxidant capacity of all co-fermented milk samples followed a similar pattern, with maximum values on d 6 of storage. The St starter, in conjunction with Ba or Lp or both, enhanced proteolysis, peptide generation, and ACE-inhibitory and antioxidant activity, but decreased $\mathrm{pH}$ values compared with St alone. The St-Ba-Lp samples showed higher DPPH ${ }^{\bullet}$ (1,1-diphenyl2-picrylhydrazyl) radical scavenging activity, hydroxyl radical scavenging activity, and total antioxidant capacity, but similar superoxide anion scavenging activity compared to St-Ba or St-Lp samples. The St-Ba samples showed higher $\mathrm{DPPH}^{\bullet}$ radical scavenging activity but lower hydroxyl radical scavenging activity than St-Lp samples. In the ACE-inhibitory assays, the St-Lp samples exhibited relatively low activity among the co-fermented milks, digested or not. The presence of $\mathrm{Ba}$ and $\mathrm{Lp}$ in fermentation together did not affect ACE-inhibitory activity in undigested fermented milks compared with the presence of Ba alone, and St-Ba-Lp fermented milks demonstrated an increase in ACEinhibitory activity after simulated gastrointestinal digestion in storage. Pepsin digestion largely improved ACE-inhibitory activity, except in St-Lp samples, in which the activity was reduced. Further hydrolysis by trypsin reduced final activity in digestion. This study suggests that co-cultured fermentation with probiotics
\end{abstract}

Received June 26, 2019.

Accepted October 1, 2019.

*Corresponding authors: stang01@126.com and heq361@163.com improves in vitro antioxidant and ACE inhibition activity in fermented milks, and this effect is partly due to the higher proteolytic activity of probiotics.

Key words: co-fermentation, proteolysis, antioxidant ability, angiotensin-converting enzyme inhibitory activity

\section{INTRODUCTION}

Oxidation in aerobic organisms produces large amounts of free radicals and active oxygen species, which can damage all types of cellular macromolecules and lead to cell death and tissue damage (Unal and Akalın, 2006). Oxidation also increases the risk of atherosclerosis, arthritis, diabetes, and cancer (Sarmadi and Ismail, 2010) in humans. Angiotensin-converting enzymes (ACE) can stimulate the production of angiotensin-II (a vasoconstrictor), which induces the release of aldosterone and elevates blood pressure (Saito et al., 2000; Turner and Hooper, 2002). It has been reported that ACE plays a key role in the regulation of blood pressure (Hernández-Ledesma et al., 2003; Chen et al., 2014). Therefore, it is of scientific and practical interesting for researchers to investigate how to inhibit ACE and improve the body's antioxidant capacity for health benefits.

Over the past 2 decades, extensive studies about the ACE-inhibitory activity of fermented milks produced by lactic acid bacteria (LAB) have been carried out (Quirós et al., 2005; Chen et al., 2014; Solieri et al., 2015). Various ACE-inhibitory peptides have been identified and characterized in dairy products (Pihlanto-Leppälä, 2001; Seppo et al., 2003). As well, casein-derived peptides and whey hydrolysates have a strong ability to chelate with transition metals and scavenge free radicals (Nishino et al., 2000; Fardet and Rock, 2018; Khan et al., 2019). Compositions such as polysaccharides from LAB possess antioxidant activity (Zhang et al., 2013), and organic acids released during fermentation may be a small source of antioxidants (Correia et al., 2005). Farvin et al. (2010) stated that the antioxidant stability of fermented dairy products could be ascribed mainly to antioxidant peptides, and 
that these peptides, as electron donors, could react with free radicals to form more stable products.

Lactobacillus plantarum and Bifidobacterium spp. are used most frequently as probiotics, and are good candidates for producing fermented milks (Gomes and Malcata, 1999; Li et al., 2017). Milk fermented by $L$. plantarum displayed 14.7 to $48.9 \%$ 1,1-diphenyl-2-picrylhydrazyl (DPPH $\mathbf{H}^{\bullet}$ ) inhibition rate (Abubakr et al., 2012) and approximately $89 \%$ ACE-inhibitory activity (Chen et al., 2018). Milk fermented with B. longum exhibited antioxidant activity (Gagnon et al., 2015) and stronger ACE-inhibitory activity than other LAB (Gonzalez-Gonzalez et al., 2011). The findings of these studies suggest that metabolites of these 2 strains have strong antioxidative and ACE-inhibitory functions.

We assumed that the combined use of starters could enhance antioxidant and ACE-inhibitory activity. Only a few studies have investigated the effects of antioxidant activity and ACE inhibition with starter combinations. Nakamura et al. (1995) demonstrated that the tripeptides Val-Pro-Pro and Ile-Pro-Pro in sour milk by co-cultures with Lactobacillus helveticus and Saccharomyces cerevisiae had hypotensive effectiveness. Madhu et al. (2012) found that yogurt prepared by fermentation with Lactobacillus plantarum, Lactobacillus delbrueckii ssp. bulgaricus, and Streptococcus thermophilus had more than $80 \% \mathrm{DPPH}^{\bullet}$ inhibitory activity. In a previous study, we found that fermented milk from $S$. thermophilus in co-cultures with a $2: 1$ ratio of L. plantarum to B. animalis ssp. lactis produced abundant amounts of peptides as a result of strong proteolysis (our unpublished data). Therefore, we hypothesized that combinations of cultures may have the potential to release bioactive peptides with antioxidant and ACE-inhibitory activity. Elucidating changes in antioxidant and ACE-inhibitory activity as a result of the interaction of these microorganisms is important for the development of health foods. However, available information about the interactive effects of $S$. thermophilus with L. plantarum and B. animalis ssp. lactis on ACE-inhibitory and antioxidant activity for fermented milk has not been reported. The objectives of this study were to investigate the effects of various culture combinations of $S$. thermophilus, L. plantarum, and $B$. animalis ssp. lactis on proteolysis and on antioxidant and ACE-inhibitory activity in fermented milk during refrigerated storage.

\section{MATERIALS AND METHODS}

\section{Bacterial Strains}

Freeze-dried probiotic strains of Lactobacillus plantarum CICC-20263 (Lp) and Bifidobacterium animalis ssp. lactis CICC-21717 (Ba) were provided by the China Center of Industrial Culture Collection (Beijing, China). The $\mathrm{Lp}$ and $\mathrm{Ba}$ were activated in de Man, Rogosa, and Sharpe (MRS) broth (Hopebio, Qingdao, China) at $37^{\circ} \mathrm{C}$ for $24 \mathrm{~h}$ under anaerobic conditions. After 2 successive transfers, the activated cultures were further inoculated into a milk medium for 6 to $7 \mathrm{~h}$ at $37^{\circ} \mathrm{C}$, which allowed for an initial population of $10^{7} \mathrm{cfu} /$ $\mathrm{mL}$ after milk inoculation. Commercial starter cultures of Streptococcus thermophilus (St) in a direct vat set form, with an activity of 250 Danisco units, were obtained from Danisco (Kunshan, China).

\section{Fermented Milk Preparation}

Fermented milks were produced using 4 culture combinations: St, St-Ba, St-Lp, and St-Ba-Lp (the ratio of $\mathrm{Ba}$ to Lp was 1:2). In all treatments, St was added at $0.1 \%$ (wt/vol) of milk (approximately $10^{8} \mathrm{cfu} / \mathrm{mL}$ ), and $\mathrm{Ba}$ and $\mathrm{Lp}$ were added alone or simultaneously at an initial concentration of $10^{7} \mathrm{cfu} / \mathrm{mL}$ of milk to commence fermentation. During preparation, fresh full-cream milk (New Hope Diary, Chengdu, China) was pasteurized at $90^{\circ} \mathrm{C}$ for $10 \mathrm{~min}$, followed by cooling to $45^{\circ} \mathrm{C}$. Then, the milk was mixed well after the addition of starter cultures according to the designated treatments. Sterilized glass cups $(100 \mathrm{~mL})$ were filled with the mixture and incubated at $42^{\circ} \mathrm{C}$ until the $\mathrm{pH}$ value decreased to 4.6. All of the fermented milk samples were transferred to a refrigerator and stored at $4 \pm 1^{\circ} \mathrm{C}$. Samples from different treatments were analyzed on d 1, 3, 6, 9, 15, and 21 of storage.

\section{pH Measurement}

The $\mathrm{pH}$ value of the fermented milk was measured using a pH meter (Sanxin, Shanghai, China) at room temperature $\left(20 \pm 2^{\circ} \mathrm{C}\right)$.

\section{Proteolytic Activity}

The degree of protein hydrolysis was evaluated using the o-phthaldialdehyde (OPA) method of Church et al. (1985). Each portion of fermented milk (2 g) was thoroughly mixed with $1 \mathrm{~mL}$ of deionized water, and then $5 \mathrm{~mL}$ of $0.75 \mathrm{M}$ trichloroacetic acid was added and mixed vigorously. After 10 min standing, the mixture was centrifuged at $4,000 \times g$ for $10 \mathrm{~min}$ at $4^{\circ} \mathrm{C}$ to obtain the supernatant. To measure proteolytic activity, $200 \mu \mathrm{L}$ of the supernatant was added to $4 \mathrm{~mL}$ of OPA reagent [50 mL of $100 \mathrm{~m} M$ sodium tetraborate, $5 \mathrm{~mL}$ of $20 \%$ (wt/wt) SDS, $80 \mathrm{mg}$ of OPA dissolved in $2 \mathrm{~mL}$ of methanol, and $200 \mu \mathrm{L}$ of $\beta$-mercaptoethanol were 
mixed and diluted to a final volume of $100 \mathrm{~mL}$ with deionized water], mixed well, and reacted at room temperature $\left(20 \pm 2^{\circ} \mathrm{C}\right)$ for $10 \mathrm{~min}$. Absorbance was read using a spectrophotometer (Aoyi, Shanghai, China) at $340 \mathrm{~nm}$. The same volume of deionized water $(200 \mu \mathrm{L})$ was added to the OPA reagent, and the absorbance of this sample served as a control.

\section{Peptide Performance}

Peptide properties were evaluated by following the method reported by Nielsen et al. (2009), with a slight modification. Fermented milks were centrifuged at 5,000 $\times g$ for $10 \min \left(4^{\circ} \mathrm{C}\right)$. The supernatants were collected, and the $\mathrm{pH}$ value was adjusted to 7.5 using $1 \mathrm{M} \mathrm{NaOH}$. The suspension (whey) was filtered through a $0.45-\mu \mathrm{m}$ filter and used to determine peptide performance.

A volume of $20 \mu \mathrm{L}$ of whey was loaded into and detected by reversed-phase HPLC (LC1260; Agilent, Santa Clara, CA). Peptides were separated on a $\mathrm{C}_{18}$ column $(4.6 \mathrm{~mm} \times 250 \mathrm{~mm}, 5 \mu \mathrm{m}$; Waters Symmetry, Milford, MA) at $30^{\circ} \mathrm{C}$ by a linear elution gradient of HPLC-grade acetonitrile (Mreda, Beijing, China) in $0.1 \%$ (vol/vol) HPLC-grade trifluoroacetic acid (Sigma-Aldrich, St. Louis, MO) from 0 to $48 \%$ between 10.0 and $90.0 \mathrm{~min}$. The flow rate was $1 \mathrm{~mL} / \mathrm{min}$, and peptide peaks were analyzed under a wavelength of 210 $\mathrm{nm}$ with a UV detector. The peptide contents of the fermented milk were evaluated by the amount of peptides present by summing the $210 \mathrm{~nm}$ peak areas in the peptide profiles. Peptide areas within 10.0 to $90.0 \mathrm{~min}$ of retention time were determined.

\section{Determination of Antioxidant Activity}

Preparation of Whey. The whey samples were separated following the method according to Virtanen et al. (2007). The $\mathrm{pH}$ value of fermented milk was adjusted to 4.6 with $1 \mathrm{M} \mathrm{HCl}$, and followed by centrifugation at $10,000 \times g$ for $10 \mathrm{~min}$ at $4^{\circ} \mathrm{C}$. The harvested supernatant was filtered through a $0.45-\mu \mathrm{m}$ filter.

DPPH Radical Scavenging Ability. The DPPH ${ }^{\bullet}$ scavenging activity of fermented milk was determined as described by Li et al. (2009). Briefly, $3 \mathrm{~mL}$ of fresh DPPH (Sigma-Aldrich) solution $(0.2 \mathrm{~m} M$ in $95 \%$ methanol) with $1 \mathrm{~mL}$ of whey sample or $95 \%$ methanol (control) were mixed well and allowed to settle for 20 min at room temperature $\left(20 \pm 2^{\circ} \mathrm{C}\right)$. After centrifugation at $10,000 \times g$ for $5 \mathrm{~min}$ at $4^{\circ} \mathrm{C}$, absorbance was measured at $517 \mathrm{~nm}$ (Aoyi). Ascorbic acid at a concentration of $0.1 \mathrm{mg} / \mathrm{mL}$ was used as positive control. The following equation was used to calculate $\mathrm{DPPH}^{\bullet}$ scavenging activity:

$$
\begin{gathered}
\text { Scavenging ratio }(\%)= \\
\left(\mathrm{A}_{\text {control }}-\mathrm{A}_{\text {sample }}\right) / \mathrm{A}_{\text {control }} \times 100,
\end{gathered}
$$

where A represents the absorbance.

Hydroxyl Radical Scavenging Activity. The method described by de Avellar et al. (2004) was employed to evaluate the ability to scavenge hydroxyl radicals. In brief, a reaction system containing $1.5 \mathrm{~mL}$ of $5 \mathrm{~m} M$ phenanthroline (Aladdin, Shanghai, China) solution, $2.0 \mathrm{~mL}$ of test samples or $0.05 \mathrm{M}$ phosphate buffer (pH 7.4), $1.0 \mathrm{~mL}$ of $\mathrm{FeSO}_{4}(7.5 \mathrm{mM}), 1 \mathrm{~mL}$ of $0.1 \% \mathrm{H}_{2} \mathrm{O}_{2}$ ( $\mathrm{vol} / \mathrm{vol}$ ), and $4.5 \mathrm{~mL}$ of deionized water was incubated at $37^{\circ} \mathrm{C}$ for $60 \mathrm{~min}$. The absorbance at $536 \mathrm{~nm}$ was monitored by spectrophotometer (Aoyi). Ascorbic acid at a concentration of $0.1 \mathrm{mg} / \mathrm{mL}$ was used as positive control. The following equation was used to calculate hydroxyl radical scavenging activity:

\section{Scavenging ratio $(\%)=\left(\mathrm{A}_{\mathrm{S}}-\mathrm{A}_{1}\right) /\left(\mathrm{A}_{0}-\mathrm{A}_{1}\right) \times 100$,}

where $A_{S}$ is the absorbance in the presence of the sample and $\mathrm{H}_{2} \mathrm{O}_{2}, \mathrm{~A}_{1}$ is the absorbance without the sample, and $\mathrm{A}_{0}$ is the absorbance without the sample and without $\mathrm{H}_{2} \mathrm{O}_{2}$.

Superoxide Anion Scavenging Ability. Superoxide anion scavenging activity was measured using the method of Liu et al. (2014). A portion of $4.5 \mathrm{~mL}$ of Tris- $\mathrm{HCl}$ buffer $(50 \mathrm{mM}, \mathrm{pH} 8.2)$ and $4.2 \mathrm{~mL}$ deionized water was incubated at $25^{\circ} \mathrm{C}$ for $20 \mathrm{~min}$, and then 0.5 $\mathrm{mL}$ of preheated whey sample and $0.3 \mathrm{~mL}$ of pyrogallol $(3 \mathrm{mM})$ dissolved in $10 \mathrm{mM} \mathrm{HCl}$ (as a control) were added and shaken vigorously. The optical densities of the reaction mixtures were determined at $320 \mathrm{~nm}$ (Aoyi). Data were collected at 30-s intervals for $270 \mathrm{~s}$ and graphed. The slope of the curve was the autoxidation rate. Ascorbic acid $(0.1 \mathrm{mg} / \mathrm{mL})$ was used as a positive control. The following equation was used to calculate superoxide anion radical scavenging activity:

$$
\text { Scavenging activity }(\%)=\left(\Delta_{\mathrm{A} 0}-\Delta_{\mathrm{A}}\right) / \Delta_{\mathrm{A} 0} \times 100,
$$

where $\Delta_{\mathrm{A} 0}$ is the autoxidation rate of control and $\Delta_{\mathrm{A}}$ is the autoxidation rate of the sample.

Total Antioxidant Capacity. The total antioxidant capacity (T-AOC) of whey samples was determined at $520 \mathrm{~nm}$ (Aoyi) using kits provided by Jiancheng Bioengineering Institute (Nanjing, China). Ascorbic acid (0.1 $\mathrm{mg} / \mathrm{mL}$ ) was used as a positive control.

\section{In Vitro ACE-Inhibitory Activity}

Simulated Gastrointestinal Digestion. Gastrointestinal digestion of fermented milk was simulated 
using pepsin and trypsin according to the method reported by Laparra et al. (2003), with minor modifications. Fermented milk was adjusted to $\mathrm{pH} 2.0$ with 6.0 $M \mathrm{HCl}$, and pepsin (Sigma-Aldrich) was added to the fermented milk at an enzyme:substrate ratio of 1:100 (wt/wt). After $2 \mathrm{~h}$ of digestion at $37^{\circ} \mathrm{C}$ and continuous stirring, the pepsin was inactivated by adjusting the $\mathrm{pH}$ to 6.8 with $0.4 \mathrm{M} \mathrm{NaOH}$. Trypsin (Sigma-Aldrich) was added at a ratio 1:100 (wt/wt) of enzyme to substrate. After $2 \mathrm{~h}$ of digestion at $37^{\circ} \mathrm{C}$, enzyme activity was terminated by heating for $10 \mathrm{~min}$ at $95^{\circ} \mathrm{C}$. Samples were digested with pepsin or trypsin alone, or in a sequential digestion of pepsin followed by trypsin, and subjected to analysis for ACE-inhibitory activity.

Determination of ACE-Inhibitory Activity. A total of $5 \mathrm{~mL}$ of fermented milk samples or digested samples were centrifuged at $5,000 \times g$ for $15 \min \left(4^{\circ} \mathrm{C}\right)$. Then, the supernatant was harvested and the $\mathrm{pH}$ was adjusted to 8.3 with $1 M \mathrm{NaOH}$. Afterward, the suspension was centrifuged at $14,000 \times g$ for 5 min at $4^{\circ} \mathrm{C}$. The collected supernatant was filtered through a $0.45-$ $\mu \mathrm{m}$ hydrophilic filter and subjected to analysis.

The ACE-inhibitory activity was evaluated following the methods of Cushman and Cheung (1971). In each assay, $60 \mu \mathrm{L}$ of sodium borate buffer $(0.1 M)$ and $30 \mu \mathrm{L}$ of peptide extraction were mixed with an aliquot $(200$ $\mu \mathrm{L}$ ) of hippuryl-histidyl-leucine (Sigma-Aldrich) solution (5 $\mathrm{m} M$ hippuryl-histidyl-leucine in $0.1 \mathrm{M}$ sodium borate buffer containing $0.3 \mathrm{M} \mathrm{NaCl}, \mathrm{pH} 8.3$ ) and incubated at $37^{\circ} \mathrm{C}$ for $10 \mathrm{~min}$. The reaction was activated by adding $20 \mu \mathrm{L}$ of ACE (Sigma-Aldrich) solution (0.1 U/ $\mathrm{mL}, \mathrm{pH} 8.3)$ and incubated in a water bath $\left(37^{\circ} \mathrm{C}\right)$ for $30 \mathrm{~min}$. The reaction was terminated by adding $250 \mu \mathrm{L}$ of $1 \mathrm{M} \mathrm{HCl}$. Then, $1.7 \mathrm{~mL}$ of ethyl acetate was added to the mixture to extract the released hippuric acid. After the samples were vigorously stirred for $10 \mathrm{~s}$, they were centrifuged at $5,000 \times g$ for $15 \mathrm{~min}\left(4^{\circ} \mathrm{C}\right)$, and 1.4 $\mathrm{mL}$ of the organic phase was transferred to a fresh test tube. The ethyl acetate was evaporated to dryness on a boiling water bath. The residue was dissolved in $3 \mathrm{~mL}$ of deionized water, and absorbance was measured using a spectrophotometer (Aoyi) at $228 \mathrm{~nm}$. The following equation was used to calculate ACE-inhibitory activity:

$$
\text { ACE inhibitory activity }(\%)=\left(1-\frac{C-D}{A-B}\right) \times 100,
$$

where $A$ is the absorbance with ACE but without the sample, $B$ is the absorbance without ACE and the sample, $C$ is the absorbance in the presence of ACE and the sample, and $D$ is the absorbance with the sample but without ACE.

\section{Statistical Analysis}

All of the assays in this study were performed in triplicate. Data were presented as mean \pm standard deviation. A $P$-value of less than 0.05 was selected as significant. All data were processed using 1-way ANOVA, the differences between pairs of treatments were calculated using Duncan's multiple comparison method, and the correlation analysis was conducted using LSD in SPSS 21.0 (IBM, Chicago, IL).

\section{RESULTS AND DISCUSSION}

\section{pH Changes}

The $\mathrm{pH}$ values of fermented milk decreased with storage time, and were significantly affected by the various strain combinations $(P<0.05)$, except on the first day of refrigerated storage (Table 1). All treatments exhibited a significant drop in $\mathrm{pH}$ values, and the maximum rate of $\mathrm{pH}$ decline occurred at $\mathrm{d} 6$ to 9 . It has also been reported that the $\mathrm{pH}$ values of fermented milk co-fermented by probiotics decreased continuously during storage (Casarotti et al., 2014; Tian et al., 2017). Fermented milk with St showed the highest $\mathrm{pH}$ value, and the St-Lp-Ba samples had the lowest values during storage. Interestingly, $\mathrm{pH}$ values in the St-Lp samples were lower than those in the St-Ba samples from d 9 to d 21; it may be that Lp has higher post-acidifying activity than Ba. Donkor et al. (2006) and Casarotti et al. (2014) noted that $\mathrm{pH}$ variations in fermented milk were related to proteolysis and appeared to depend on storage time and the post-acidifying activity of the starters.

\section{Proteolysis in Fermented Milk}

Milk proteins are hydrolyzed by extracellular proteinases released by LAB, resulting in rising levels of free amino groups as quantified by the OPA method (Church et al., 1985). Proteolysis data for milk protein during the $21 \mathrm{~d}$ of storage are plotted in Figure 1. Proteolytic activity in all fermented milk samples increased over the storage period. Similar findings have been reported by Ramchandran and Shah (2009) and Madhu et al. (2012). Fermented milk with co-cultures had stronger proteolytic activity than St treatment alone $(P<0.05)$, a further indication of the proteolytic activity of the probiotic strains. It was apparent that samples fermented by Lp demonstrated stronger proteolytic activity than those without Lp during storage, and this may further prove the capacity for protein hydrolysis of Lp. Moslehishad et al. (2013) found that $L$. 
Table 1. $\mathrm{pH}$ value of fermented milk during $21 \mathrm{~d}$ of refrigerated storage at $4^{\circ} \mathrm{C}^{1}$

\begin{tabular}{|c|c|c|c|c|c|c|}
\hline Culture $^{2}$ & \multicolumn{6}{|c|}{ Storage day } \\
\hline $\begin{array}{l}\text { St } \\
\text { St-Ba } \\
\text { St-Lp } \\
\text { St-Ba-Lp }\end{array}$ & $\begin{array}{l}4.49 \pm 0.02^{\mathrm{a}, \mathrm{A}} \\
4.49 \pm 0.01^{\mathrm{a}, \mathrm{A}} \\
4.48 \pm 0.00^{\mathrm{a}, \mathrm{A}} \\
4.48 \pm 0.01^{\mathrm{a}, \mathrm{A}}\end{array}$ & $\begin{array}{l}4.48 \pm 0.01^{\mathrm{ab}, \mathrm{A}} \\
4.46 \pm 0.02^{\mathrm{b}, \mathrm{AB}} \\
4.46 \pm 0.01^{\mathrm{b}, \mathrm{AB}} \\
4.44 \pm 0.01^{\mathrm{b}, \mathrm{B}}\end{array}$ & $\begin{array}{l}4.46 \pm 0.02^{\mathrm{b}, \mathrm{A}} \\
4.43 \pm 0.01^{\mathrm{c}, \mathrm{B}} \\
4.42 \pm 0.01^{\mathrm{c}, \mathrm{BC}} \\
4.41 \pm 0.01^{\mathrm{c}, \mathrm{C}}\end{array}$ & $\begin{array}{l}4.38 \pm 0.01^{\mathrm{c}, \mathrm{A}} \\
4.36 \pm 0.01^{\mathrm{d}, \mathrm{B}} \\
4.35 \pm 0.01^{\mathrm{d}, \mathrm{C}} \\
4.34 \pm 0.00^{\mathrm{d}, \mathrm{D}}\end{array}$ & $\begin{array}{l}4.35 \pm 0.01^{\mathrm{d}, \mathrm{A}} \\
4.33 \pm 0.01^{\mathrm{e}, \mathrm{B}} \\
4.31 \pm 0.01^{\mathrm{e}, \mathrm{C}} \\
4.28 \pm 0.00^{\mathrm{e}, \mathrm{D}}\end{array}$ & $\begin{array}{l}4.27 \pm 0.01^{\mathrm{e}, \mathrm{A}} \\
4.26 \pm 0.01^{\mathrm{f}, \mathrm{A}} \\
4.21 \pm 0.01^{\mathrm{f}, \mathrm{B}} \\
4.21 \pm 0.01^{\mathrm{f}, \mathrm{B}}\end{array}$ \\
\hline
\end{tabular}

\footnotetext{
${ }^{\mathrm{a}-\mathrm{f}}$ Means within the same row with different superscripts indicate significant differences among days of storage $(P<0.05)$.

${ }^{\mathrm{A}-\mathrm{D}}$ Means within the same column with different superscripts indicate significant differences among starters $(P<0.05)$.

${ }^{1}$ Data are expressed as mean $\pm \mathrm{SD}$.

${ }^{2} \mathrm{St}=$ Streptococcus thermophilus $; \mathrm{St}-\mathrm{Ba}=$ S. thermophilus and Bifidobacterium animalis ssp. lactis; St-Lp $=$ S. thermophilus and Lactobacillus plantarum; St-Ba-Lp $=$ S. thermophilus with 2:1 of L. plantarum and B. animalis ssp. lactis.
}

plantarum exhibited a high level of proteolytic activity among the tested strains. Shihata and Shah (2000) reported that Bifidobacterium spp. had lower proteolysis than other LAB. These distinctions in the proteolytic activity of strains may be the result of variations in their proteolytic systems.

\section{Peptide Performance}

Figure 2 shows the total areas of peptides in fermented milk throughout the storage period. The peptide areas for St-Ba, St-Lp, and St-Ba-Lp treatments rapidly elevated to a peak at d $6(P<0.05)$, followed by a reduction during the further storage; St samples exhibited their highest peak value at d 9. As expected, all fermented milk samples from co-cultures presented

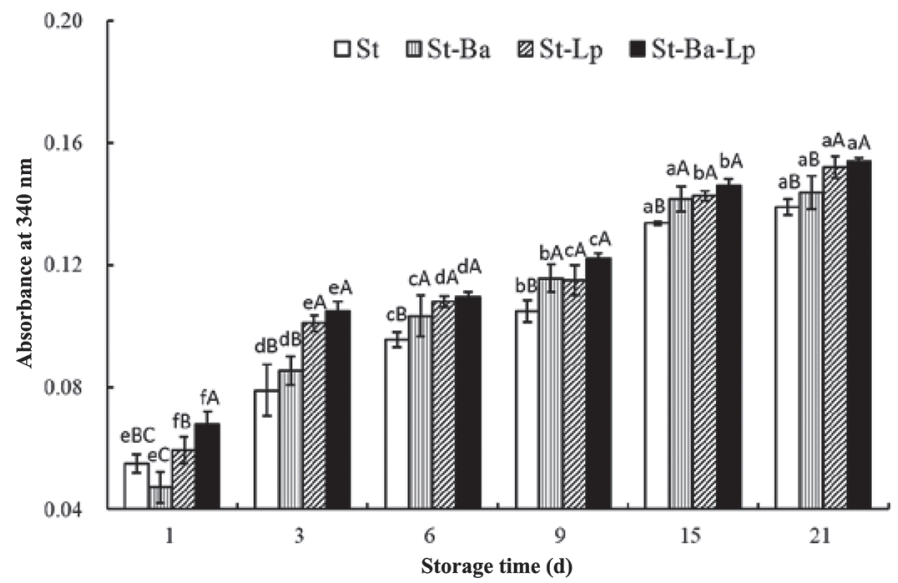

Figure 1. Changes in proteolysis of fermented milk during $21 \mathrm{~d}$ of refrigerated storage at $4^{\circ} \mathrm{C}$. Error bars represent SD. Means with different lowercase letters $(\mathrm{a}-\mathrm{f})$ were significantly different for each type of fermented milk among days of storage $(P<0.05)$; means with different uppercase letters $(\mathrm{A}-\mathrm{C})$ were significantly different for a particular day of storage for each parameter $(P<0.05)$. St $=$ Streptococcus thermophilus; $\mathrm{St}-\mathrm{Ba}=S$. thermophilus and Bifidobacterium animalis ssp. lactis; St-Lp $=$ S. thermophilus and Lactobacillus plantarum; St-Ba-Lp $=S$. thermophilus with $2: 1$ of L. plantarum and B. animalis ssp. lactis. more peptide contents than pure St cultures from $\mathrm{d} 1$ to 21 of storage $(P<0.05)$. However, we found no observable difference in peptide area among co-cultures $(P>$ $0.05)$ during storage. The proteolytic system involves a series of processes, including caseins being hydrolyzed into peptides and transported into cells, then further decomposed to a series of small peptides and amino acids by intracellular peptidases (Nielsen et al., 2009). Changes during proteolysis may result in the generation of more bioactive peptides (Shahidi and Zhong, 2008).

\section{Antioxidant Ability}

The antioxidant properties of fermented milk were estimated using 4 assay systems in vitro: $\mathrm{DPPH} \cdot$ scav-

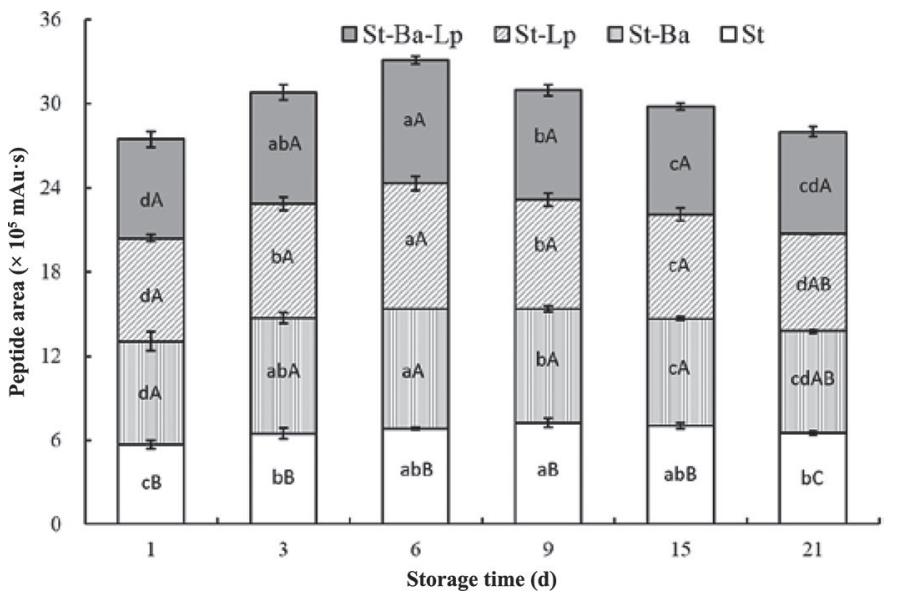

Figure 2. Peptide area $\left(\times 10^{5} \mathrm{mAu} \cdot \mathrm{s}\right)$ of fermented milk determined by HPLC during $21 \mathrm{~d}$ of refrigerated storage at $4^{\circ} \mathrm{C}$. Error bars represent SD. Means with different lowercase letters (a-d) were significantly different for each type of fermented milk among days of storage $(P<0.05)$; means with different uppercase letters $(\mathrm{A}-\mathrm{C})$ were significantly different for a particular day of storage for each parameter $(P<0.05)$. St $=$ Streptococcus thermophilus; St-Ba $=S$. thermophilus and Bifidobacterium animalis ssp. lactis; St-Lp $=S$. thermophilus and Lactobacillus plantarum; St-Ba-Lp $=S$. thermophilus with 2:1 of $L$. plantarum and B. animalis ssp. lactis. 
enging activity, hydroxyl radical scavenging activity, superoxide anion radical scavenging activity, and total antioxidant capacity.

$D P P H^{\bullet}$ Scavenging Activity. The $\mathrm{DPPH}^{\bullet}$ radical is a stable, long-lived, organic nitrogen radical, and the scavenging of $\mathrm{DPPH}^{\bullet}$ assay is commonly used to evaluate the antioxidant activity of products (Sharma and Bhat, 2009). Our findings (Figure 3) showed that probiotics increased $\mathrm{DPPH}^{\bullet}$ scavenging activity during storage. The antioxidant activity of the treatments demonstrated a down-upward tendency during storage. The highest $\mathrm{DPPH}^{\bullet}$ scavenging activity for all treatments occurred at $\mathrm{d} 1$, and the lowest $\mathrm{DPPH}^{\bullet}$ scavenging activity was observed at d 9. Similar trends of $\mathrm{DPPH}^{\bullet}$ scavenging activity during storage for plain cow milk yogurt have been reported by Shori (2013) and Nikjooy and Hashemi (2015). The decrease in $\mathrm{DPPH}^{\bullet}$ scavenging activity is probably because of higher hydrolysis and cleavage in regions of bioactive peptides with antioxidant activity (Najaf et al., 2019). At $0.1 \mathrm{mg} / \mathrm{mL}$, the scavenging activity of ascorbic acid in the present study was $79.12 \%$. The co-cultured samples showed higher antioxidant potential than the St samples $(P<0.05)$. The St-Ba-Lp samples showed the highest $\mathrm{DPPH}^{\bullet}$ scavenging activity, followed by the St-Ba and St-Lp samples. The DPPH ${ }^{\bullet}$ scavenging activity was negatively correlated with peptide amounts $(P<0.05)$.

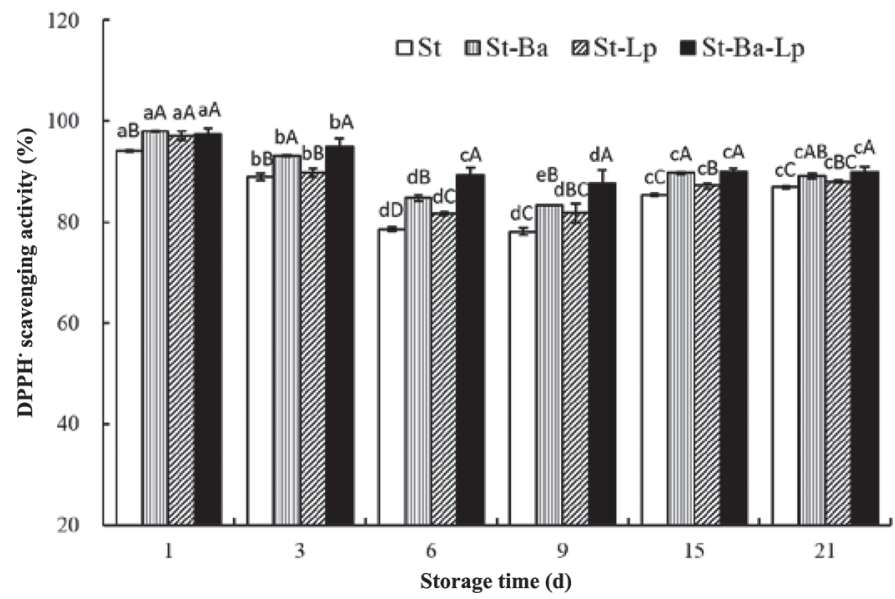

Figure 3. 1,1-Diphenyl-2-picrylhydrazyl (DPPH ${ }^{\bullet}$ ) radical scavenging activity of fermented milk during $21 \mathrm{~d}$ of refrigerated storage at $4^{\circ} \mathrm{C}$. Error bars represent SD. Means with different lowercase letters (a-e) were significantly different for each type of fermented milk among days of storage $(P<0.05)$; means with different uppercase letters (A-D) were significantly different for a particular day of storage for each parameter $(P<0.05)$. St $=$ Streptococcus thermophilus; St-Ba $=S$. thermophilus and Bifidobacterium animalis ssp. lactis; $\mathrm{St-Lp}=S$. thermophilus and Lactobacillus plantarum; St-Ba-Lp $=S$. thermophilus with $2: 1$ of L. plantarum and B. animalis ssp. lactis.
Hydroxyl Radical Scavenging Activity. Hydroxyl radical is the most highly reactive oxygen radical known (Zhang et al., 2013). The scavenging activity of hydroxyl radical by the fermented milks increased to its highest values $(90.35,91.31,94.21$, and $95.62 \%$ for St, St-Ba, St-Lp, and St-Ba-Lp, respectively) on d 6 of storage, followed by a gradual decrease to between 80 and $84 \%$ on d 21 (Figure 4). Ascorbic acid demonstrated a scavenging activity of $70.93 \%$. The order of hydroxyl radical scavenging activity in the fermented milks, from high to low, was St-Ba-Lp, St-Lp, St-Ba, and St $(P<0.05)$. Li et al. $(2015)$ reported that coculture increased the hydroxyl radical scavenging activity of fermented milk compared with a single LAB culture, similar to our findings. However, the changes in all fermented milks during storage with respect to hydroxyl radical scavenging activity were nonsignificant $(P>0.05)$ over $9 \mathrm{~d}$ of storage. It may be that the composition of the starter cultures did not have a lasting effect on hydroxyl radical scavenging activity over the storage period. However, the scavenging activity did have a strong positive correlation with peptide amounts $(P<0.05)$.

Superoxide Anion Radical Scavenging Activity. Superoxide anions are free radicals with unpaired electrons on oxygen, and they indirectly initiate lipid oxidation as a result of superoxide and hydrogen peroxide, serving as precursors of singlet oxygen and

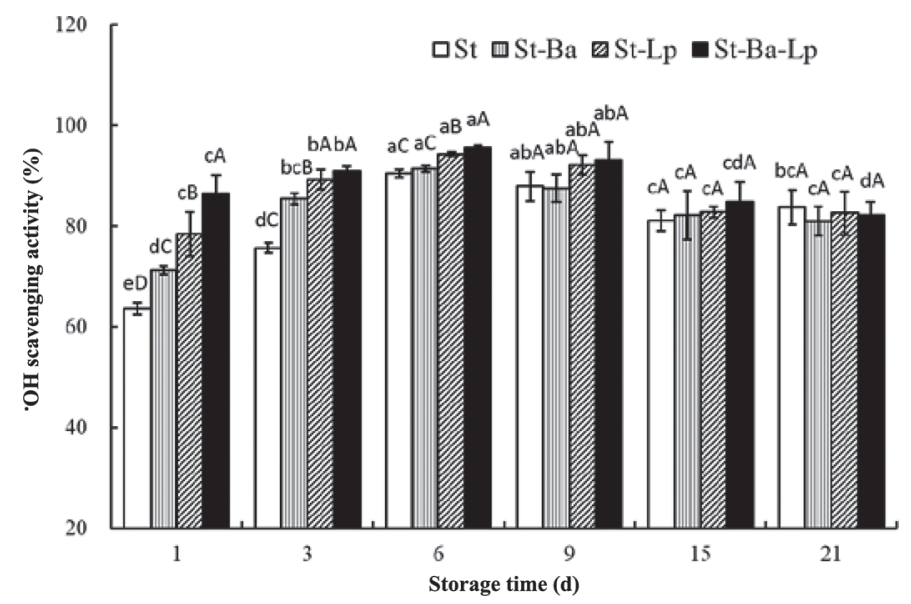

Figure 4. Hydroxyl radical scavenging capacity of fermented milk during $21 \mathrm{~d}$ of refrigerated storage at $4^{\circ} \mathrm{C}$. Error bars represent SD. Means with different lowercase letters $(\mathrm{a}-\mathrm{e})$ were significantly different for each type of fermented milk among days of storage $(P$ $<0.05)$; means with different uppercase letters $(\mathrm{A}-\mathrm{D})$ were significantly different for a particular day of storage for each parameter $(P$ $<0.05) . \mathrm{St}=$ Streptococcus thermophilus; $\mathrm{St}-\mathrm{Ba}=S$. thermophilus and Bifidobacterium animalis ssp. lactis; St-Lp $=$ S. thermophilus and Lactobacillus plantarum; St-Ba-Lp $=S$. thermophilus with $2: 1$ of $L$. plantarum and B. animalis ssp. lactis. 


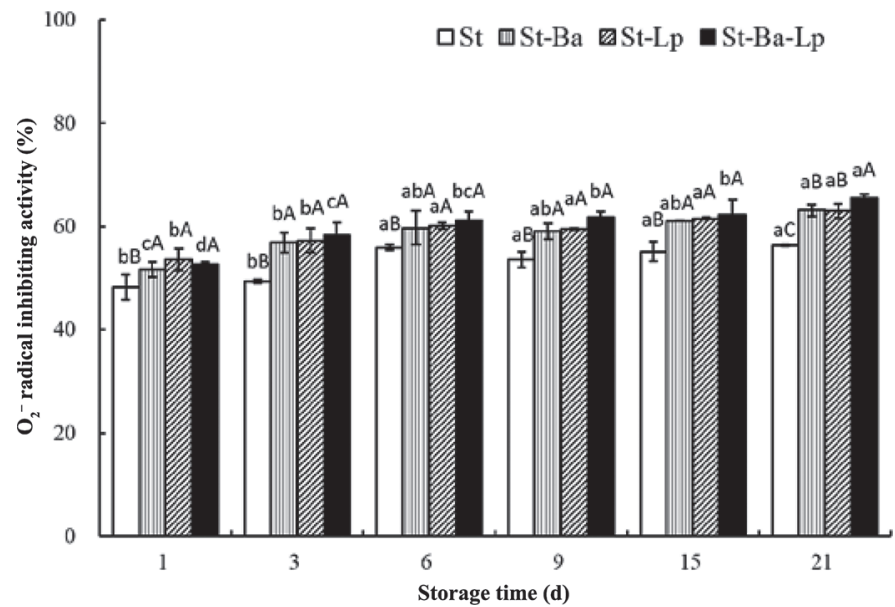

Figure 5. Superoxide anion radical scavenging activity of fermented milk during $21 \mathrm{~d}$ of refrigerated storage at $4^{\circ} \mathrm{C}$. Error bars represent SD. Means with different lowercase letters $(\mathrm{a}-\mathrm{d})$ were significantly different for each type of fermented milk among days of storage $(P$ $<0.05$ ); means with different uppercase letters $(\mathrm{A}-\mathrm{C})$ were significantly different for a particular day of storage for each parameter $(P$ $<0.05) . \mathrm{St}=$ Streptococcus thermophilus; St-Ba $=S$. thermophilus and Bifidobacterium animalis ssp. lactis; $\mathrm{St-Lp}=$ S. thermophilus and Lactobacillus plantarum; St-Ba-Lp $=S$. thermophilus with 2:1 of $L$. plantarum and B. animalis ssp. lactis.

hydroxyl radicals (Karadag et al., 2009). As shown in Figure 5, the superoxide anion radical scavenging activity of all samples was time-dependent $(P<0.05)$, and values varied from $48.24 \pm 2.44$ to $65.50 \pm 0.72 \%$, depending on the starter culture used. The superoxide anion radical scavenging activity of the fermented milk samples was higher than that of $0.1 \mathrm{mg} / \mathrm{mL}$ ascorbic acid $(31.20 \%)$. The co-cultures demonstrated a favorable ability to eliminate superoxide anion radicals, and noticeably higher scavenging activity than that of the St samples $(P<0.05)$. In particular, the St-BaLp samples showed the highest scavenging activity of superoxide anions over the $21 \mathrm{~d}$ of storage. Wang et al. (2006) reported that the superoxide anion radical scavenging activity of soy milk prepared from both $S$. thermophilus and B. infantis was $65.04 \%$ after $24 \mathrm{~h}$ fermentation, whereas $S$. thermophilus single cultures exhibited only $58.34 \%$ activity. It is reasonable to postulate that $S$. thermophilus co-cultured with probiotics can resist oxidation of superoxide anions. We observed no significant relationship between scavenging activity and peptide content for the co-culture samples $(P>$ $0.05)$, but the St samples showed positive correlations $(P<0.05)$. This finding suggests that co-fermentation of probiotics with $S$. thermophilus changed the metabolites with superoxide anion scavenging activity.

Total Antioxidant Capacity. The T-AOC of food depends on a variety of antioxidation mechanisms; any single antioxidant index cannot explain T-AOC. The T-AOC of all batches of fermented milks increased gradually up to $\mathrm{d} 6$, and then decreased until d 21 (Table 2). Reduced antioxidant capacity is usually because of degradation of antioxidants (Yuksel et al., 2010). The T-AOC of the fermented milk samples was lower than that of ascorbic acid $(6.82 \mathrm{U} / \mathrm{mg}$ protein). The co-cultured samples presented more effective TAOC than the samples with St only $(P<0.05)$, but after $6 \mathrm{~d}$, we found no significant differences among the treatments. The co-cultured samples improved the TAOC of fermented milk, possibly because of microbial metabolic interactions, resulting in increased peptides with antioxidant activity. Statistical analysis demonstrated positive correlations between T-AOC and peptide content for the fermented samples throughout storage $(P<0.05)$ except for the St samples, which exhibited no significant positive correlation $(P>0.05)$. Archibald and Fridovich (1981) reported that the ability to produce superoxide dismutase could be one of the main factors accounting for the high superoxide anion scavenging effect of the $S$. thermophilus fermented milk. The T-AOC of fermented milk is related not only to peptide content, but also to some metalloproteins and amino acids.

Table 2. Total antioxidant capacity ( $\mathrm{U} / \mathrm{mg}$ of protein) of fermented milk during $21 \mathrm{~d}$ of refrigerated storage at $4^{\circ} \mathrm{C}^{1}$

\begin{tabular}{|c|c|c|c|c|c|c|}
\hline Culture $^{2}$ & \multicolumn{6}{|c|}{ Storage day } \\
\hline $\begin{array}{l}\text { St } \\
\text { St-Ba } \\
\text { St-Lp } \\
\text { St-Ba-Lp } \\
\text { Ascorbic acid }\end{array}$ & $\begin{array}{l}4.26 \pm 0.06^{\mathrm{b}, \mathrm{C}} \\
4.56 \pm 0.12^{\mathrm{b}, \mathrm{B}} \\
4.72 \pm 0.15^{\mathrm{b}, \mathrm{B}} \\
5.03 \pm 0.22^{\mathrm{b}, \mathrm{A}}\end{array}$ & $\begin{array}{l}4.13 \pm 0.06^{\mathrm{b}, \mathrm{C}} \\
4.66 \pm 0.32^{\mathrm{b}, \mathrm{B}} \\
4.79 \pm 0.03^{\mathrm{ab}, \mathrm{B}} \\
5.16 \pm 0.14^{\mathrm{b}, \mathrm{A}}\end{array}$ & $\begin{array}{r}4.59 \pm 0.10^{\mathrm{a}, \mathrm{C}} \\
5.06 \pm 0.12^{\mathrm{a}, \mathrm{B}} \\
5.15 \pm 0.14^{\mathrm{a}, \mathrm{B}} \\
5.49 \pm 0.06^{\mathrm{a}, \mathrm{A}} \\
6.8\end{array}$ & $\begin{array}{l}3.62 \pm 0.26^{\mathrm{c}, \mathrm{A}} \\
3.86 \pm 0.28^{\mathrm{c}, \mathrm{A}} \\
3.70 \pm 0.25^{\mathrm{c}, \mathrm{A}} \\
3.86 \pm 0.16^{\mathrm{c}, \mathrm{A}} \\
0.14\end{array}$ & $\begin{array}{l}3.78 \pm 0.07^{\mathrm{c}, \mathrm{A}} \\
3.66 \pm 0.14^{\mathrm{c}, \mathrm{A}} \\
3.52 \pm 0.44^{\mathrm{cd}, \mathrm{A}} \\
3.58 \pm 0.25^{\mathrm{cd,A}}\end{array}$ & $\begin{array}{l}3.21 \pm 0.12^{\mathrm{d}, \mathrm{A}} \\
3.25 \pm 0.07^{\mathrm{d}, \mathrm{A}} \\
3.25 \pm 0.07^{\mathrm{d}, \mathrm{A}} \\
3.45 \pm 0.12^{\mathrm{d}, \mathrm{A}}\end{array}$ \\
\hline
\end{tabular}


Summary. The St-Ba-Lp samples had the highest total antioxidant activity, but the T-AOC of the fermented milks during storage did not change significantly between the St-Ba and St-Lp samples $(P>0.05)$. The St-Lp samples showed lower $\mathrm{DPPH}^{\bullet}$ scavenging activity but higher hydroxyl radical inhibition than the St-Ba samples, implying that the St-Ba and St-Lp samples used different mechanisms to resist oxidant attack. Sarmadi and Ismail (2010) noted that the antioxidative performance of the peptides from food proteins is closely related to the composition, structure, and hydrophobicity of the peptides. Based on these findings, we speculate that the development of free radical inhibition was connected to the specific proteolytic enzymes obtained from the microbial strains.

\section{ACE-Inhibitory Activity}

During the fermentation of dairy products, intense proteolysis takes place, resulting in the production of ACE-inhibitory peptides (Anne et al., 2010; Rai et al., 2017). These peptides can exert an antihypertensive effect in vivo if they reach the cardiovascular system in an activated state (Vermeirssen et al., 2004). Thus, these peptides need to resist complete degradation by gastrointestinal proteases after oral administration. Peptides can be hydrolyzed, leading to the activation or inactivation of their ACE-inhibitory activity during gastrointestinal digestion (Vaštag et al., 2013; Jin et al., 2016).

All samples showed inhibitory activity against ACE (Table 3). A rising trend in ACE-inhibitory activity first emerged, followed by a decline, and this decreased ability suggested the possibility of cleavage of the structure of peptides with ACE-inhibitory ability during long-term hydrolysis (Hata et al., 1996). In contrast to the St samples, the co-cultures showed a higher ACE inhibition effect over the $21 \mathrm{~d}$ of storage. Up to $9 \mathrm{~d}$, we detected no visible difference in ACE inhibition among the co-cultures. However, after $15 \mathrm{~d}$ of storage, the cocultures containing Ba showed higher ACE-inhibitory activity than those without $\mathrm{Ba}$, demonstrating the ACE-inhibitory activity of peptides from bifidobacteria (Ramchandran and Shah, 2008). We found highly positive correlations between peptide content and ACE-inhibitory effect for all fermented milks during storage $(P<0.05)$.

Pepsin treatment for fermented milks improved the ACE-inhibitory activity of gastric digests, with the exception of St-Lp. The increase in activity was closely

Table 3. Angiotensin-converting enzyme inhibition activity (\%) of fermented milk during $21 \mathrm{~d}$ of refrigerated storage at $4^{\circ} \mathrm{C}^{1}$

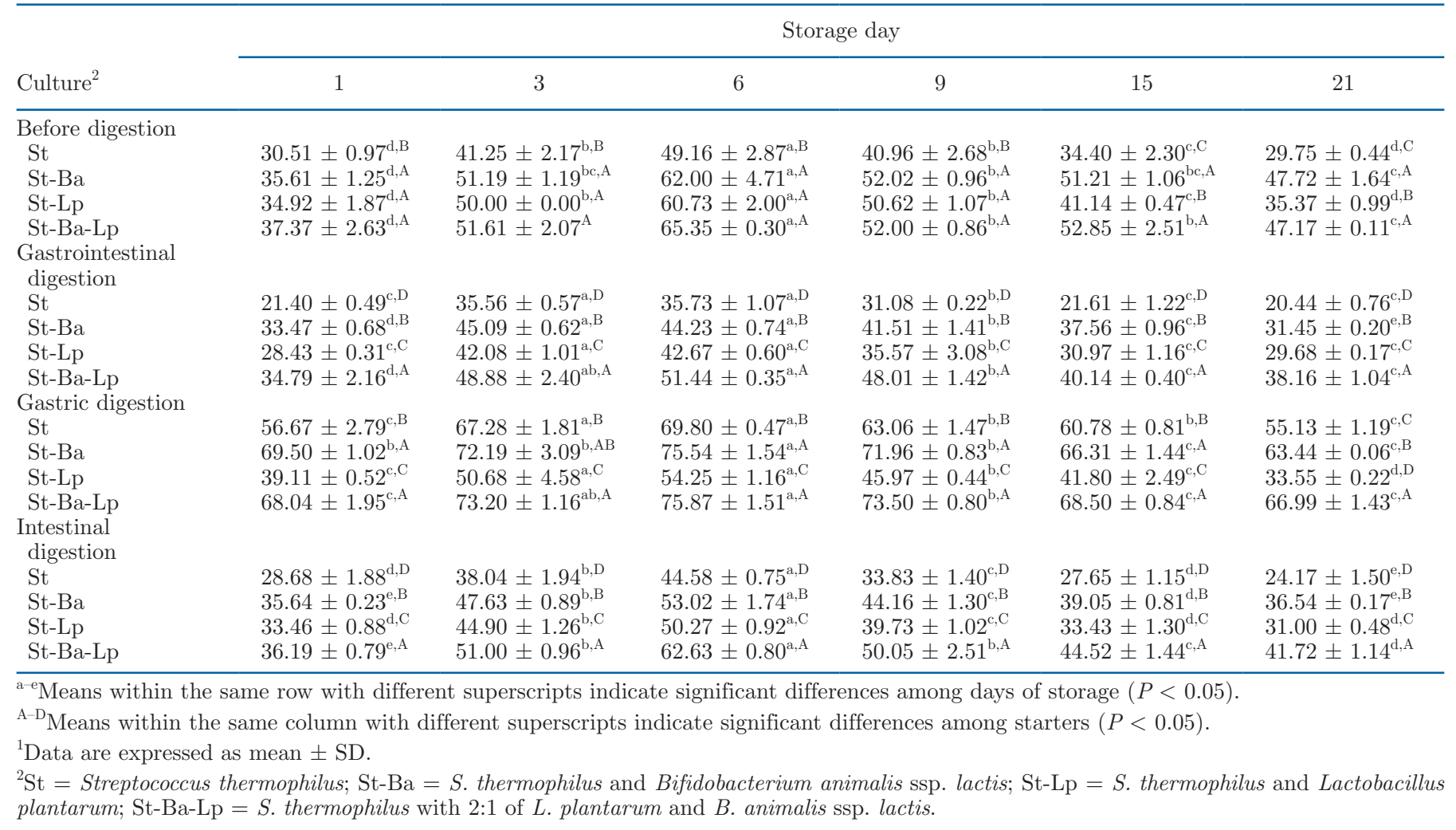


related to the release of new ACE-inhibitory peptides during gastric digestion (Quirós et al., 2005; Jin et al., 2016), and also because some ACE-inhibitory peptides in fermented milk are resistant pepsin (Contreras et al., 2013). In contrast, the ACE-inhibitory peptides showed instability with trypsin treatment, and trypsin hydrolysis reduced the effectiveness of ACE-inhibitory peptides. We observed a similar phenomenon in samples digested by pepsin and then trypsin. This finding suggested that further digestion by pancreatic enzymes might weaken the ACE inhibition of gastric digests, resulting in no significant change in ACE-inhibitory activity in the final digest. Quirós et al. (2005) reported that ACE inhibition after simulated digestion was similar to or slightly lower than that of undigested peptides, except for peptide $\beta$-CN f (47-52) (DKIHPF). HernándezLedesma et al. (2007) observed a moderate decrease in ACE-inhibitory activity for peptide fragments LQKW and LLF after simulated digestion. However, Jin et al. (2016) demonstrated that the ACE inhibition rate of the pancreatic digests was greater than that of yogurt and gastric digests. The St-Ba-Lp and St-Ba samples showed higher ACE-inhibitory activity than the StLp samples after applying different combinations of simulated digestive juices. Furthermore, we observed a relatively high ACE-inhibitory rate for all St-Ba-Lp samples compared with St-Ba samples after trypsin or pepsin-trypsin digestion, but found no differences in the untreated or pepsin-digested fermented milks. This finding was probably because microbial metabolic interactions resulting in the C-terminal residue of peptides produced by co-cultures of 3 strains involved more proline. Proline as the $\mathrm{C}$-terminal residue could be primarily responsible for the high activity (Cheung et al., 1980; Quirós et al., 2005). Interestingly, the ACE inhibition of the St-Lp fermented milk was lower than that of the St fermented milk after pepsin digestion, implying that some of the active sequences of peptides from St-Lp samples were totally hydrolyzed after digestion (Vercruysse et al., 2005). Similar results were reported by Quirós et al. (2005), who revealed that the loss of the C-terminal sequence RYL could be responsible for a decline in ACE-inhibitory properties.

Although we observed higher proteolytic capacity in St-Lp fermented milk than in St-Ba and no difference between St-Lp and St-Ba in terms of peptide production, the ACE inhibition of the St-Lp samples was lower than that of the St-Ba samples. This finding indicated that biological activity is not directly correlated with the proteolytic activity of starters. Instead, amino acid composition, as well as the size and sequence of these amino acids in peptides, may play a vital role in biological activity (Vermeirssen et al., 2003; Gómez-Ruiz et al., 2004; Salami et al., 2011).

\section{CONCLUSIONS}

This study showed that $S$. thermophilus co-cultured with L. plantarum or B. animalis ssp. lactis formed suitable combinations for exerting appreciable antioxidant and ACE inhibition in vitro. The peptide generation and ACE-inhibitory activity of co-fermented milk showed similar trends to T-AOC, and reached statistical peak values on $\mathrm{d}$ 6. The St-Ba-Lp starters demonstrated the highest activity for proteolysis, antioxidant activity, and ACE inhibition after digestion. The co-cultures of St-Ba and St-Lp exhibited similar trends and very similar T-AOC. The St-Ba co-culture showed higher DPPH radical scavenging activity but lower hydroxyl radical scavenging activity than the St-Lp co-culture. Pepsin digestion largely improved the ACE inhibition activity of the fermented milks, except for the St-Lp samples; however, hydrolysis by trypsin reduced final activity in digestion. This study suggests that combinations of probiotics in fermented milk could improve its functional components and activities, and the optimal shelf life is within $6 \mathrm{~d}$ after production.

\section{ACKNOWLEDGMENTS}

This work was funded by Central University Fund Program (Grant No. 2018NQN48, Chengdu, China) and Sichuan Provincial Major Science and Technology Program (Grant No. 2018NZ0003, Chengdu, China).

\section{REFERENCES}

Abubakr, M. A. S., Z. Hassan, M. M. A. Imdakim, and N. R. S. A. Sharifah. 2012. Antioxidant activity of lactic acid bacteria (LAB) fermented skim milk as determined by 1,1-diphenyl-2-picrylhydrazyl (DPPH) and ferrous chelating activity (FCA). Afr. J. Microbiol. Res. 6:6358-6364.

Anne, P., V. Tarja, and K. Hannu. 2010. Angiotensin I converting enzyme (ACE) inhibitory activity and antihypertensive effect of fermented milk. Int. Dairy J. 20:3-10.

Archibald, F. S., and I. Fridovich. 1981. Manganese, superoxide dismutase, and oxygen tolerance in some lactic acid bacteria. J. Bacteriol. 146:928-936.

Casarotti, S. N., D. A. Monteiro, M. M. S. Moretti, and A. L. B. Penna. 2014. Influence of the combination of probiotic cultures during fermentation and storage of fermented milk. Food Res. Int. 59:67-75.

Chen, L., Q. H. Zhang, Z. Ji, G. W. Shu, and H. Chen. 2018. Production and fermentation characteristics of angiotensin-I-converting enzyme inhibitory peptides of goat milk fermented by a novel wild Lactobacillus plantarum 69. Lebensm. Wiss. Technol. 91:532-540.

Chen, Y., W. Liu, J. Xue, J. Yang, X. Chen, Y. Shao, L. Y. Kwok, M. Bilige, L. Mang, and H. Zhang. 2014. Angiotensin-converting enzyme inhibitory activity of Lactobacillus helveticus strains from traditional fermented dairy foods and antihypertensive effect of fermented milk of strain H9. J. Dairy Sci. 97:6680-6692.

Cheung, H. S., F. L. Wang, M. A. Ondetti, E. F. Sabo, and D. W. Cushman. 1980. Binding of peptide substrates and inhibitors of angiotensin-converting enzyme: Importance of the $\mathrm{COOH}$-terminal dipeptide sequence. J. Biol. Chem. 255:401-407. 
Church, F. C., D. H. Porter, G. L. Catignani, and H. E. Swaisgood. 1985. An o-phthalaldehyde spectrophotometric assay for proteinases. Anal. Biochem. 146:343-348.

Contreras, M. D., D. Sanchez, M. A. Sevilla, I. Recio, and L. Amigo. 2013. Resistance of casein derived bioactive peptides to simulated gastrointestinal digestion. Int. Dairy J. 32:71-78.

Correia, I., A. Nunes, I. F. Duarte, A. Barros, and I. Delgadillo. 2005. Sorghum fermentation followed by spectroscopic techniques. Food Chem. 90:853-859.

Cushman, D. W., and H. S. Cheung. 1971. Spectrophotometric assay and properties of the angiotensin-converting enzyme of rabbit lung. Biochem. Pharmacol. 20:1637-1648.

de Avellar, I. G., M. M. Magalhães, A. B. Silva, L. L. Souza, A. C. Leitão, and M. Hermes-Lima. 2004. Reevaluating the role of 1,10-phenanthroline in oxidative reactions involving ferrous ions and DNA damage. Biochim. Biophys. Acta. 1675:46-53.

Donkor, O. N., A. Henriksson, T. Vasiljevic, and N. P. Shah. 2006. Effect of acidification on the activity of probiotics in yoghurt during cold storage. Int. Dairy J. 16:1181-1189.

Fardet, A., and E. Rock. 2018. In vitro and in vivo antioxidant potential of milks, yoghurts, fermented milks and cheeses: A narrative review of evidence. Nutr. Res. Rev. 31:52-70.

Farvin, S., C. Baron, N. S. Nielsen, and C. Jacobsen. 2010. Antioxidant activity of yoghurt peptides: Part 1-in vitro assays and evaluation in omega-3 enriched milk. Food Chem. 123:1081-1089.

Gagnon, M., P. Savard, A. Rivière, G. LaPointe, and D. Roy. 2015. Bioaccessible antioxidants in milk fermented by Bifidobacterium longum ssp. longum strains. BioMed Res. Int. 2015:169381.

Gomes, A. M. P., and F. X. Malcata. 1999. Bifidobacterium spp. and Lactobacillus acidophilus: Biological, biochemical, technological, and therapeutical properties relevant for use as probiotics. Trends Food Sci. Technol. 10:139-157.

Gómez-Ruiz, J. A., M. Ramos, and I. Recio. 2004. Angiotensin-converting enzyme-inhibitory activity of peptides isolated from Manchego cheese. Stability under simulated gastrointestinal digestion. Int. Dairy J. 14:1075-1080.

Gonzalez-Gonzalez, C. R., K. M. Tuohy, and P. Jauregi. 2011. Production of angiotensin-I converting enzyme (ACE) inhibitory activity in milk fermented with probiotic strains: Effects of calcium, $\mathrm{pH}$ and peptides on the ACE-inhibitory activity. Int. Dairy J. 21:615-622.

Hata, Y., M. Yamamoto, M. Ohni, K. Nakajima, Y. Nakamura, and T. Takano. 1996. A placebo-controlled study of the effect of sour milk on blood pressure in hypertensive subjects. Am. J. Clin. Nutr. 64:767-771.

Hernández-Ledesma, B., P. J. Martín-Álvarez, and E. Pueyo. 2003. Assessment of spectrophotometric method for determination of angiotensin converting enzyme activity: influence of inhibition type. J. Agric. Food Chem. 51:4175-4179.

Hernández-Ledesma, B., M. Miguel, L. Amigo, M. A. Aleixandre, and I. Recio. 2007. Effect of simulated gastrointestinal digestion on the antihypertensive properties of synthetic $\beta$-lactoglobulin peptide sequences. J. Dairy Res. 74:336-339.

Jin, Y., Y. Yu, Y. X. Qi, F. J. Wang, J. Z. Yan, and H. F. Zou. 2016. Peptide profiling and the bioactivity character of yogurt in the simulated gastrointestinal digestion. J. Proteomics 141:24-46.

Karadag, A., B. Ozcelik, and S. Saner. 2009. Review of methods to determine antioxidant capacities. Food Anal. Methods 2:41-60.

Khan, I. T., M. Nadeem, M. Imran, R. Ullah, M. Ajmal, and M. H. Jaspal. 2019. Antioxidant properties of milk and dairy products: A comprehensive review of the current knowledge. Lipids Health Dis. 18:41.

Laparra, J. M., D. Vélez, R. Montoro, R. Barberá, and R. Farré. 2003. Estimation of arsenic bioaccessibility in edible seaweed by an in vitro digestion method. J. Agric. Food Chem. 51:6080-6085.

Li, C., J. Song, L. Y. Kwok, J. Wang, Y. Dong, H. Yu, Q. Hou, H. Zhang, and Y. Chen. 2017. Influence of Lactobacillus plantarum on yogurt fermentation properties and subsequent changes during postfermentation storage. J. Dairy Sci. 100:2512-2525.
Li, W., F. S. Hosseinian, A. Tsopmo, J. K. Friel, and T. Beta. 2009. Evaluation of antioxidant capacity and aroma quality of breast milk. Nutrition 25:105-114.

Li, Y., T. J. Liu, and G. Q. He. 2015. Antioxidant activity of peptides from fermented milk with mix culture of lactic acid bacteria and yeast. Adv. J. Food Sci. Technol. 7:422-427.

Liu, F., W. Du, X. Bai, and S. Tian. 2014. Quantification of phytochemical constituents and in vitro antioxidant activity of Althaea rosea seeds. J. Chem. Pharm. Res. 6:1466-1471.

Madhu, A. N., N. Amrutha, and S. G. Prapulla. 2012. Characterization and antioxidant property of probiotic and synbiotic yogurts. Probiotics Antimicrob. Proteins 4:90-97.

Moslehishad, M., S. Mirdamadi, M. R. Ehsani, H. Ezzatpanah, and A. A. Moosavi-Movahedi. 2013. The proteolytic activity of selected lactic acid bacteria in fermenting cow's and camel's milk and the resultant sensory characteristics of the products. Int. J. Dairy Technol. 66:279-285.

Najaf, M. B. H., S. S. Fatemizadeh, and M. Tavakoli. 2019. Release of proteolysis products with ACE-inhibitory and antioxidant activities in probiotic yogurt containing different levels of fat and prebiotics. Int. J. Pept. Res. Ther. 25:367-377.

Nakamura, Y., N. Yamamoto, K. Sakai, A. Okubo, S. Yamazaki, and T. Takano. 1995. Purification and characterization of angiotensin I-converting enzyme inhibitors from sour milk. J. Dairy Sci. 78:777-783.

Nielsen, M. S., T. Martinussen, B. Flambard, K. I. Sørensen, and J. Otte. 2009. Peptide profiles and angiotensin-I-converting enzyme inhibitory activity of fermented milk products: Effect of bacterial strain, fermentation $\mathrm{pH}$, and storage time. Int. Dairy J. 19:155165.

Nikjooy, S., and S. H. Hashemi. 2015. Study the possibility of producing symbiotic yogurt containing Lactobacillus casei and wild thyme extract. Int. J. Agric. Crop Sci. 8:61-67.

Nishino, T., H. Shibahara-Sone, H. Kikuchi-Hayakawa, and F. Ishikawa. 2000. Transit of radical scavenging activity of milk products prepared by Maillard reaction and Lactobacillus casei strain Shirota fermentation through the hamster intestine. J. Dairy Sci. 83:915-922.

Pihlanto-Leppälä, A. 2001. Bioactive peptides derived from bovine whey proteins: Opioid and ACE-inhibitory peptides. Trends Food Sci. Technol. 11:347-356.

Quirós, A., B. Hernández-Ledesma, M. Ramos, L. Amigo, and I. Recio. 2005. Angiotensin-converting enzyme inhibitory activity of peptides derived from caprine kefir. J. Dairy Sci. 88:3480-3487.

Rai, A. K., S. Sanjukta, and K. Jeyaram. 2017. Production of angiotensin I converting enzyme inhibitory (ACE-I) peptides during milk fermentation and their role in reducing hypertension. Crit. Rev. Food Sci. Nutr. 57:2789-2800.

Ramchandran, L., and N. Shah. 2008. Proteolytic profiles and angiotensin-I converting enzyme and $\alpha$-glucosidase inhibitory activities of selected lactic acid bacteria. J. Food Sci. 73:M75-M81.

Ramchandran, L., and N. P. Shah. 2009. Effect of exopolysaccharides and inulin on the proteolytic, angiotensin-I-converting enzymeand $\alpha$-glucosidase-inhibitory activities as well as on textural and rheological properties of low-fat yogurt during refrigerated storage. Dairy Sci. Technol. 89:583-600.

Saito, T., T. Nakamura, H. Kitazawa, Y. Kawai, and T. Itoh. 2000. Isolation and structural analysis of antihypertensive peptides that exist naturally in Gouda cheese. J. Dairy Sci. 83:1434-1440.

Salami, M., A. A. Moosavi-Movahedi, F. Moosavi-Movahedi, M. R. Ehsani, R. Yousefi, M. Farhadi, A. Niasari-Naslaji, A. A. Saboury, J. M. Chobert, and T. Haertlé. 2011. Biological activity of camel milk casein following enzymatic digestion. J. Dairy Res. $78: 471-478$

Sarmadi, B. H., and A. Ismail. 2010. Antioxidative peptides from food proteins: A review. Peptides 31:1949-1956.

Seppo, L., T. Jauhiainen, T. Poussa, and R. Korpela. 2003. A fermented milk high in bioactive peptides has a blood pressure-lowering effect in hypertensive subjects. Am. J. Clin. Nutr. 77:326-330. 
Shahidi, F., and Y. Zhong. 2008. Bioactive peptides. J. AOAC Int. 91:914-931.

Sharma, O. P., and T. K. Bhat. 2009. DPPH antioxidant assay revisited. Food Chem. 113:1202-1205.

Shihata, A., and N. P. Shah. 2000. Proteolytic profiles of yogurt and probiotic bacteria. Int. Dairy J. 10:401-408.

Shori, A. B. 2013. Antioxidant activity and viability of lactic acid bacteria in soybean-yogurt made from cow and camel milk. J. Taibah University Sci. 7:202-208.

Solieri, L., G. S. Rutella, and D. Tagliazucchi. 2015. Impact of nonstarter lactobacilli on release of peptides with angiotensin-converting enzyme inhibitory and antioxidant activities during bovine milk fermentation. Food Microbiol. 51:108-116.

Tian, H., Y. Shen, H. Yu, Y. He, and C. Chen. 2017. Effects of 4 probiotic strains in coculture with traditional starters on the flavor profile of yogurt. J. Food Sci. 82:1693-1701.

Turner, A. J., and N. M. Hooper. 2002. The angiotensin-converting enzyme gene family: Genomics and pharmacology. Trends Pharmacol. Sci. 23:177-183.

Unal, G., and A. S. Akalın. 2006. Antioxidant activity of milk proteins. Agro Food Ind. Hi-Tech 17:4-6.

Vaštag, Z., L. Popović, S. Popović, I. Peričin-Starčević, and V. KrimerMalešević. 2013. In vitro study on digestion of pumpkin oil cake protein hydrolysate: Evaluation of impact on bioactive properties. Int. J. Food Sci. Nutr. 64:452-460.

Vercruysse, L., G. Smagghe, G. Herregods, and J. V. Camp. 2005. ACE inhibitory activity in enzymatic hydrolysates of insect protein. J. Agric. Food Chem. 53:5207-5211.

Vermeirssen, V., A. V. D. Bent, J. V. Camp, A. V. Amerongen, and W. Verstraete. 2004. A quantitative in silico analysis calculates the angiotensin I converting enzyme (ACE) inhibitory activity in pea and whey protein digest. Biochimie 86:231-239.

Vermeirssen, V., J. V. Camp, L. Devos, and W. Verstraete. 2003. Release of angiotensin-I converting enzyme (ACE) inhibitory activity during in vitro gastrointestinal digestion: From batch experiment to semicontinuous model. J. Agric. Food Chem. 51:5680-5687.

Virtanen, T., A. Pihlanto, S. Akkanen, and H. Korhonen. 2007. Development of antioxidant activity in milk whey during fermentation with lactic acid bacteria. J. Appl. Microbiol. 102:106-115.

Wang, Y. C., R. C. Yu, and C. C. Chou. 2006. Antioxidative activities of soymilk fermented with lactic acid bacteria and bifidobacteria. Food Microbiol. 23:128-135.

Yuksel, Z., E. Avci, and Y. K. Erdem. 2010. Characterization of binding interactions between green tea flavonoids and milk proteins. Food Chem. 121:450-456.

Zhang, L., C. H. Liu, D. Li, Y. J. Zhao, X. Zhang, X. P. Zeng, Z. N. Yang, and S. Y. Li. 2013. Antioxidant activity of an exopolysaccharide isolated from Lactobacillus plantarum C88. Int. J. Biol. Macromol. 54:270-275.

\section{ORCIDS}

S. N. Li (1) https://orcid.org/0000-0001-5260-4015

S. H. Tang $\odot$ https://orcid.org/0000-0002-2416-4443

Q. He $\odot$ https://orcid.org/0000-0001-5901-5627

J. X. Hu ৫ https://orcid.org/0000-0002-3300-2219

J. Zheng @ https://orcid.org/0000-0002-4277-9636 